УДК 007.51

А. М. Дзінько, Л. С. Ямпольський

\title{
ДИСКРЕТНО-СТОХАСТИЧА МОДЕЛЬ РУХУ МАТЕРІАЛЬНИХ ПОТОКІВ В КОНТЕКСТІ ЗАДАЧІ ДИСПЕТЧЕРИЗАЦІї
}

Анотація: запропонована дискретно-стохастична модель руху матеріальних потоків в логістичних системах на базі економіко-математичної моделі ланцюжків поставок для застосування при вирішенні задачі диспетчеризування матеріальних потоків.

Ключові слова: логістична система, матеріальний потік, дискретно-стохастична модель, економіко-математична модель, ланцюжки поставок, мережа масового обслуговування.

\section{Ветуп}

Задача диспетчеризування матеріальних потоків в логістичних системах з кожним роком стає все більш актуальною, і тому з'являється все більше досліджень, спрямованих на вирішення задач перепланування ланцюжків поставок. Такі дослідження ставлять перед собою за ціль виконання певних оптимізаційних задач, серед яких найбільш частими є:

1. Мінімізація вартості роботи логістичної системи при заданому об’ємі матеріальних потоків.

2. Максимізація об’єму проходження матеріальних потоків при обмеженні вартості побудови, перепланування та/чи обслуговування логістичної системи [1].

Кожен розділ логістики пропонує різні способи вирішення вказаних задач, що, зазвичай різниться в залежності від типу логістичної системи, проте природа матеріальних потоків є однаковою у всіх цих системах [2].

Тому видається доцільним побудувати таку модель руху матеріальних потоків, яка б абстрагувалась від особливостей конкретних систем, а працювала б виключно з універсальними характеристиками матеріальних потоків та потокоутворюючих об’єктів.

\section{Постановка задачі}

Розробити таку математичну модель руху матеріальних потоків, що дозволяла б вирішувати задачу диспетчеризації матеріальних потоків між вузлами системи та відповідала б наступним вимогам:

1. Висока універсальність.

(c) А. М. Дзінько, Л. С. Ямпольський 
2. Розподілений характер моделі, що відображатиме розподілену структуру логістичних систем, а також дозволятиме застосовувати не лише проблемно-орієнтований, а й агентноорієнтований підхід до вирішення задачі диспетчеризації [3].

3. «Потокоцентричність» - модель повинна відображати властивості матеріальних потоків.

4. Наявність принципової можливості втілення математичної моделі у вигляді комп’ютерної моделі, в тому числі з можливостю реалізації функцій імітаційного моделювання.

\section{Економіко-мателатична модель ланцюжків поставок}

Однією з існуючих моделей, що майже задовільняють викладені вище вимоги є економіко-математична модель ланцюжків поставок Лісовського-Пономаренко - неперервно-стохастична модель, що базується на математичному апараті мереж масового обслуговування (MeMO) [1].

Вищезгадана модель представляє всю логістичну систему як граф, що складається з переплетених лінійних ланцюгів поставок (рис. 1).

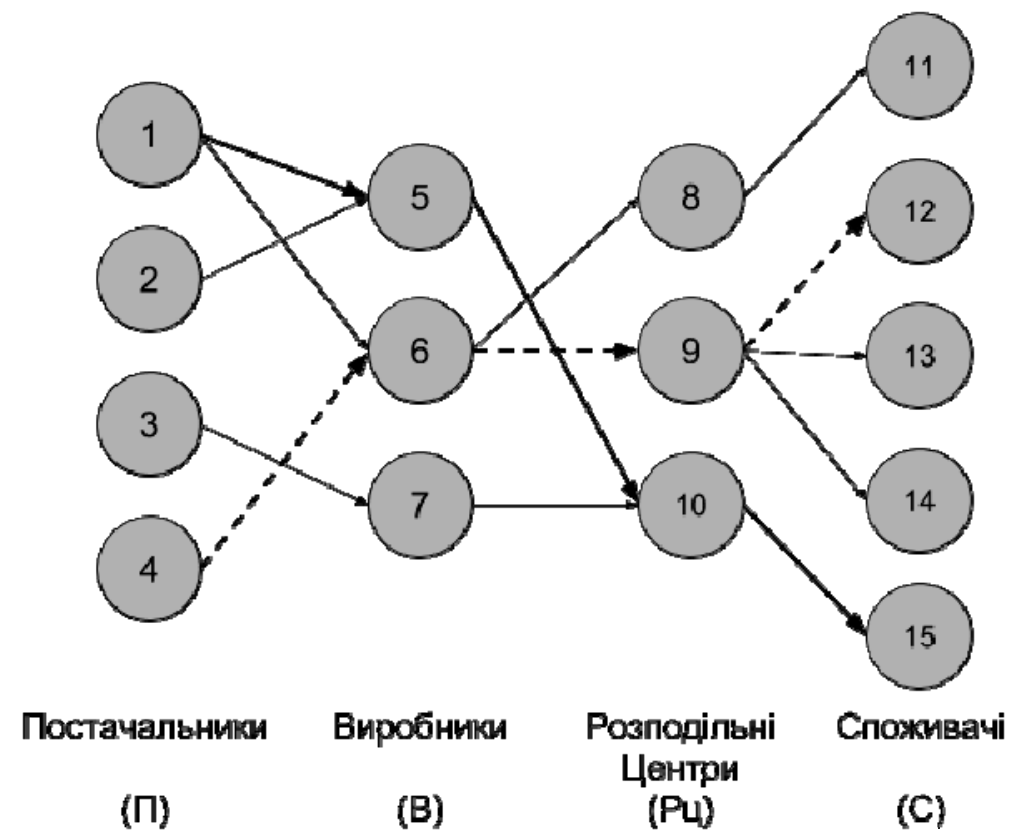

Рис. 1. Приклад системи ланцюжків поставок

Для прикладу, з даного рисунку, можемо виділити ланцюжки поставок: «П1-В5-Рц10-С15», «П4-В6-Рц9-С12», та ін.

Нехай $N$ - кількість вузлів в мережі поставок, а $K$ - стала кіль- 
кість вимог у МеMO, а $k_{i}$ - кількість вимог в $i$-му вузлі, $m_{i}-$ кількість паралельних каналів обслуговування в $i$-му вузлі, $\mu_{i}$ - інтенсивність обслуговування вимог в $i$-му вузлі. Тоді отримаємо наступні характеристики, що моделюють стан системи, в якій обробляються $R$ різних типів вимог [1]:

1. Рівняння потоку МеMО для розімкнутої (1.1) та замкнутої (1.2) мереж задає залежність інтенсивності вимог в $i$-му вузлі $\lambda_{i}$ від інтенсивностей вимог на інших вузлах 3 урахуванням ймовірності маршрутизації $p_{i j}$ :

$$
\begin{gathered}
\lambda_{i}=\lambda_{0 i}+\sum_{j=1}^{N} \lambda_{j} p_{i j}, i=1 . . \mathrm{N} \\
\lambda_{i}=\sum_{j=1}^{N} \lambda_{j} p_{i j}, i=1 . . \mathrm{N},
\end{gathered}
$$

де $\lambda_{i}$ - інтенсивність вимог, що надходять до вузла, $p_{i j}$ - ймовірність маршрутизації (переходу вимоги з одного вузла на інший).

2. Маргінальна ймовірність стану вузла $\pi_{i}(k)$, що показує ймовірність того, що в $i$-му вузлі знаходиться вектор $k=S_{i}$ різнотипних вимог:

$$
\pi_{i}(k)=\sum \pi\left(\mathrm{S}_{1}, \ldots, \mathrm{S}_{R}\right)
$$

3. Завантаженість вузла вимогами $r$-го типу:

$$
\rho_{i r}=\frac{1}{m_{i}} \sum_{k: k_{i}>0} \pi_{i}(k) \frac{k_{i r}}{k} \min \left(m_{i}, \mathrm{k}_{i}\right), k_{i}=\sum_{r=1}^{R} k_{i r}
$$

4. Пропускна спроможність вузла:

$$
\lambda_{i r}=\sum_{k: k_{i}>0} \pi_{i}(k) \frac{k_{i r}}{k_{i}} \mu_{i}\left(k_{i}\right)
$$

Вищенаведені характеристики дозволяють описати систему також такими середніми величинами як середня кількість вимог у вузлі, середня довжина черги, та середній час очікування вимог у черзі вузла, i, хоча, така модель відповідає вимогам універсальності, розподіленості, та потокоорієнтованості, вона не надає можливості вирішувати задачі диспетчеризації матеріальних потоків. 
Диспетчеризація повинна враховувати відхилення від нормального (запланованого) ходу роботи, а також попереджувати такі відхилення, а, отже, модель повинна описувати не лише стан системи в плановому (штатному) режимі роботи, а й стани системи в кожен момент часу, що веде за собою врахування відхилень роботи вузлів ЛС від планових.

\section{Дискретно-стохастична модель руху матеріальних потоків}

Для того, щоб позбутись вищевказаних недоліків, введемо в модель додатковий інваріант - час. Оскільки, при вирішенні задачі диспетчеризації нас не цікавить перебіг процесів перетворення матеріальних потоків, а лише сам факт зміни характеристик системи 3 виникненням в ній подій [5], визначимо час дискретним.

Таким чином, нехай є деяка логістична система:

$$
L S=\left\{L S^{0}, L S^{p}, \varphi\right\}
$$

де $L S^{0}$ - деякий відомий стан системи в момент часу $t=0$ (початок роботи чи моделювання), а $\varphi$ - функція диспетчеризації, що виконує перехід системи з одного стану в інший. Тоді:

$$
L S^{0}=\left\{\lambda_{i r}^{0}, \pi_{i}^{0}(\mathrm{k}), \rho_{i r}^{0}, \ldots\right\}
$$

а стан системи в кожен наступний $(t+1)$ момент часу обчислюється як корекція значень $\mu_{i}\left(k_{i}\right)$ та $\lambda_{i}$ шляхом застосування функції маршрутизації $\varphi$ :

$$
L S^{t+1}=\varphi\left(\mathrm{p}_{i j}^{t} \lambda_{i r}^{t}, \pi_{i}^{t}(\mathrm{k}), \rho_{i r}^{t}\right)
$$

а плановий стан роботи системи $L S^{p}$ задаємо як описано в попередньому параграфі статті:

$$
L S^{p}=\left\{\lambda_{i r}, \pi_{i}(\mathrm{k}), \rho_{i r}\right\}
$$

Оскільки, у процесі відхилення роботи системи від запланованого, змінюються ймовірності переходів станів вузлів $\pi_{i}(k)$, ціллю функції диспетчеризації (7) є мінімізація відхилення значень цього вектора від його значення в нормальному стані:

$$
\min \left(\sum_{i=1 . . N, j=1 . . N}\left|\mathrm{p}_{i j}^{t}-\mathrm{p}_{i j}^{p}\right|\right)
$$




$$
p_{i j}^{t+T_{d}}=p_{i j}^{p}
$$

де $T_{d}$ - час диспетчеризації. $\mathrm{V}$ випадку запланованого режиму роботи системи функція $\varphi$ є функцією ідентичності, тобто $T_{d}=0$.

Для адаптації початкової моделі до виконання задач диспетчеризації, в неї був введений новий інваріант - час, а також функція диспетчеризації $\varphi$, що переводить модель системи з одного стану в інший 3 ціллю нівелювання відхилення від нормального (планового режиму роботи). Таким чином, модель, що описувала стан системи статично, отримала характеристику опису динаміки руху матеріальних потоків.

Для кожного моменту часу функція диспетчеризації $\varphi$ визначена на інтервалах $\left(t ; t+T_{d}\right]$ та $\left(\mathrm{T}_{d} ;+\infty\right)$. У випадку нормального (планового) режиму роботи системи $T_{d}=0$.

Окремий інтерес представляє можливість застосування моделі в комбінації з мультиагентним підходом до вирішення задачі диспетчеризації матеріальних потоків.

\section{Висновки}

В даній роботі запропонована дискретно-стохастична модель руху матеріальних потоків в логістичних системах, що базується на економіко-математичній моделі ланцюжків поставок Лісовського-Пономаренка.

Подана модель володіє властивостями:

- універсальності - абстрагується від конкретних логістичних систем чи їх видів, що забезпечується засобами теорії МO;

- розподіленості - окремо описує кожен вузол та його вхідний потік заявок;

- потокоорієнтованості - основні модельовані характеристики відображають основні властивості матеріальних потоків: початкова та кінцева точки (напрям), швидкість руху, номенклатура об’єктів потоку (через різнотипність заявок).

- простота побудови колn'ютерної моделі - на базі розробленої математичної моделі можна побудувати комп'ютерну, в тому числі імітаційну модель роботи логістичної системи. 
Таким чином, володіючи цими характеристиками, розроблена математична модель задовільняє вимоги, вказані при постановці задачі.

В якості напрямку подальших досліджень варто обрати пошук функції маршрутизації $\varphi$, яка, власне, й виконує диспетчеризацію матеріальних потоків.

\section{Список використаних джерел}

6. Економіко-математична модель логістичного ланцюжка поставок / Лісовський В. І., Пономаренко Л. А. // Збірник наукових праць МННЦ ITiC «Економіко-математичне моделювання соціально-економічних систем». - 2012. - № 17. - С. 5-22.

7. Логістичний підхід до диспетчеризації матеріальних потоків ГВС / Дзінько А. М., Ямпольський Л. С. // Міжвідомчий науковотехнічний збірник «Адаптивні системи автоматичного управління». - 2013. - №1(22). - С. 17-24.

8. Агентно-орієнтований підхід до розв'язання логістичних задач диспетчеризації матеріальних потоків / Дзінько А. М., Ямпольський Л. С. // Міжвідомчий науково-технічний збірник «Адаптивні системи автоматичного управління». - 2012. - №21(41). C. $18-22$.

9. Подходы к алгоритмизации диспетчерского управления в логистических системах / Васецкий В. В., Питолин В. М. // Вестник Воронежского Государственного Технического Университета. 2012. - №1 (том 8). - С. 11-16.

10. Гнучкі комп'ютеризовані системи: проектування, моделювання i управління: Підручник / Л. С. Ямпольський, П. П. Мельничук, Б. Б. Самотокін, М. М. Поліщук, М. М. Ткач, К. Б. Остапченко, О. І. Лісовиченко. - ЖКитомир: ЖЋДТУ, 2005. - 680 с. 